\title{
Article
}

\section{Second language pragmatics}

Wang, Jiayi and Halenko, Nicola

Available at http://clok.uclan.ac.uk/28406/

Wang, Jiayi ORCID: 0000-0003-2720-8218 and Halenko, Nicola ORCID: 00000002-9906-6418 (2019) Second language pragmatics. East Asian Pragmatics, 4 (1). pp. 1-9. ISSN 2055-7752

It is advisable to refer to the publisher's version if you intend to cite from the work. http://dx.doi.org/10.1558/eap.38206

For more information about UCLan's research in this area go to http://www.uclan.ac.uk/researchgroups/ and search for < name of research Group>.

For information about Research generally at UCLan please go to http://www.uclan.ac.uk/research/

All outputs in CLoK are protected by Intellectual Property Rights law, including Copyright law. Copyright, IPR and Moral Rights for the works on this site are retained by the individual authors and/or other copyright owners. Terms and conditions for use of this material are defined in the policies page.

\section{CLoK}

Central Lancashire online Knowledge www.clok.uclan.ac.uk

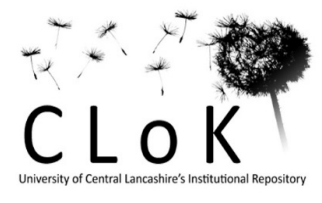




\title{
Special issue of East Asian Pragmatics: Second language pragmatics Introduction
}

\author{
Jiayi Wang and Nicola Halenko
}

Second language pragmatics, also known as interlanguage pragmatics, "investigates how L2 learners develop the ability to understand and perform action in a target language" (Kasper \& Rose, 2002, p. 5). Being pragmatically competent in another language is considered an essential component of being a successful communicator, as outlined in a number of leading influential frameworks of communicative competence (Bachman \& Palmer, 1996; Canale \& Swain, 1980; Hymes, 1972). These early frameworks advocate not only the importance of knowing the constructs of a language, but having the ability to use language in socially appropriate ways. For instance, when requesting a favour from someone, in addition to knowing what forms and lexis are needed to produce the request (grammatical competence), users need to consider their linguistic choices in light of acceptability of the request according to the local cultural norms, the specific situation, the favour itself, and from whom they are soliciting the favour (pragmatic competence). Both competencies are inextricably linked and need equal attention in the language-learning process. Leech (1983) and Thomas (1983) describe pragmatic competence as the sum of two specific components: 'pragmalinguistics' (the knowledge of linguistic resources needed for communication) and 'sociopragmatics' (the knowledge of sociocultural rules which govern these resources). Second language pragmatics investigations often draw on these distinctions when evaluating and assessing L2 performance.

Recently, second language pragmatic investigations have begun to highlight the interplay of interactional and intercultural competences in the language-learning process given today's interconnected societies within which language users now operate. Kizu, Pizziconi, and Gyogi’s paper in this issue, which investigates inter- 
actional competence of L2 Japanese learners, is a good example of a move in this direction. Interactional competency (see studies by Ishida, 2009; Taguchi, 2014) is characterised as learners bringing a variety of linguistic and semiotic resources to jointly contribute to ongoing discourse and co-accomplish specific language goals (Young, 2011). Intercultural competency, according to Fantini and Tirmizi (2006, p. 12), is "a complex of abilities needed to perform effectively and appropriately when interacting with others who are linguistically and culturally different from oneself" (see recent studies by McConachy, 2018 and Sánchez-Hernández \& Alcón-Soler, 2018). These alternatives to established models of competency offer an additional window within which to view and analyse what it means to be a successful language user in today's multicultural and multilingual society. The prefix 'inter' is a defining trait of these alternative visions by focusing on the shared, rather than on the individual, as early competency models appeared to emphasise. The spotlight on the co-constructiveness of communicative action is highlighted in LoCastro's (2003) definition of second language pragmatics as follows: "[it is] the study of the speaker and hearer meaning created in their joint actions that include both linguistic and non-linguistic signals in the context of socioculturally organised activities" (p. 15).

The importance of language learners developing a reasonable level of pragmatic competence is clearly underlined by Thomas (1983), who states that pragmatic infelicities may reflect badly on you as a person when interactions fail to adhere to expected cultural norms and linguistic practices. Despite the potential for such high-risk consequences, pragmatics research consistently reports L2 language users falling short of target-like pragmatic norms. So, what are the main issues leading to this reported shortfall in pragmatic competency, which is evident even in advanced L2 language users? First, much of the pragmatic knowledge native speakers (NSs) possess is intuitive with no codified rules of use (Cook, 2001). It is learned and developed through social interaction and, assuming accessibility, can be a slow process (Cohen, 2008; Taguchi, 2010). Earlier estimates have suggested up to ten years (Olshtain \& Blum-Kulka, 1985), yet some researchers suggest competency may never be achieved despite permanent residency in an L2 context (Cohen, 2008; Kasper \& Rose, 2002). Second, transfer of L1 pragmatic norms may positively or negatively affect L2 communication. Pragmatic transfer is defined by Kasper (1997, p. 119) as the "use of L1 pragmatic knowledge to understand or carry out linguistic action in the L2". On the positive side, adult learners, for example, have access to a considerable amount of pragmalinguistic and sociopragmatic knowledge which can be successfully transferred to the L2, such as an understanding of social positions of power which affect linguistic choice. Conversely, negative L1 transfer can also occur when language users are unfamiliar with target language conventions and L1-L2 mapping strategies

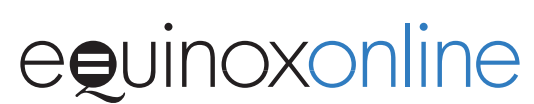


are incorrectly, and unintentionally, applied. An understanding of where these cross-cultural gaps lie is therefore critical. Studies such as Su and Chang (this issue), which attempt to systematically outline L1 (Chinese) practices, offer particularly helpful cultural insights which can then be used to inform L2 teaching and learning practices. Third, it is important to note that, despite having some pragmatic awareness, L2 users do not always manage to utilise this knowledge. As Kasper contends, learners will often rely on literal interpretation of utterances instead of utilising inference or contextual clues (1997, p. 3) due to low proficiency or limited exposure to the L2. Finally, in some cases, learners may not be willing to actively adopt L2 pragmatics practices despite an ability to do so. This resistance to change has been noted in numerous studies to varying degrees and is generally driven by prioritising the self, one's identity, or core L1 belief systems, for instance. Inagaki's paper (this issue) also provides insights into the role affective factors such as motivation can play in developing pragmatic awareness when immersed in a study abroad environment. The notion of willingness to communicate (WTC), which the author discusses, has also been previously linked to resistance to L2 interaction.

\section{East Asian pragmatics and L2 learning}

Pragmatics of East Asian languages as a second or foreign language is much less researched than that of European and American languages such as English, French, and Spanish. However, recent years have witnessed a growing number of pragmatic studies of East Asian languages, most notably Japanese and Chinese as a second or foreign language, though it is worth mentioning that the latter, e.g. Japanese as a foreign language (JFL) or Chinese as a foreign language (CFL), tends to be subsumed under the former, i.e. Japanese as a second language (JSL) or Chinese as a second language (CSL). We adopt the often-used term L2 as a generic label to refer to both henceforth. While L1 pragmatics has spawned a wealth of research on East Asian languages, e.g. Matsumoto (1988) on L1 Japanese and Pan and Kádár (2011) on L1 Chinese politeness, L2 East Asian pragmatics has been a relatively nascent area of inquiry.

Japanese is the most studied East Asian language in the field of L2 pragmatics, and it has the longest history of research. Dozens of studies have been published on teaching, learning, and assessing L2 Japanese pragmatics. Both receptive and productive skills have been explored. For example, Cook (2001) reported the failure of American college learners of Japanese to distinguish polite from impolite speech styles when listening to the self-introductions of three job applicants due to their misunderstanding of the Japanese pragmatic features. The receptive skills of listening and reading and the productive skills of speaking and writing have been examined from various perspectives, covering an array of pragmatic

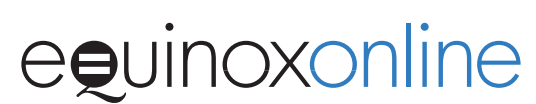


features ranging from honorifics to sentence-final particles such as ne, from reactive tokens to formulaic utterances. For instance, Taguchi's (2015a) book-length study examined the development of interactional competence among L2 Japanese learners during their semester abroad in Japan, focusing on the learners' change in the use of speech styles (polite and plain forms), style-shifting between the polite and plain forms across different participant structures, and functions of incomplete sentence endings in joint turn construction (around a communication problem, for the display of empathetic understanding, and for assisted explanation). Taguchi's (2009) edited volume is another book that is wholly dedicated to learners of L2 Japanese, among a vast body of L2 Japanese pragmatics research.

Chinese is the second most studied East Asian language in L2 pragmatics next to Japanese, but in fact, the upsurge in research interest in L2 Chinese pragmatics is more recent. Kasper (1995) edited the first and only book of pragmatics of Chinese as a native and a foreign language. There are six chapters in Kasper's volume. Five chapters analyse the patterns of native Chinese speakers' strategies to perform certain speech acts such as requests, refusals, complaints, and compliments. Only one chapter is about L2 Chinese learners. It analyses the learners' experiences of developing pragmatics during their period abroad in China, including complimenting, refusals, and requests. The findings suggest that "explicit teaching of Chinese pragmatics is advisable" (Kasper and Zhang, 1995, p. 19), calling for more research on L2 Chinese pragmatics. At the time of Kasper and Zhang's (1995) study, Chinese pragmatics research was minimal, and there were virtually no studies on the acquisition and use of Chinese pragmatics by non-native speakers. In Taguchi's (2015b) meta-analysis of pragmatics in Chinese as a second or foreign language, she highlights that her exhaustive search of literature yielded only 14 data-based studies of Chinese learners' pragmatic competence and development published up to 2015. Kasper's (1995) edited volume was and in fact is still the only book devoted to L1 and L2 Chinese pragmatics. The relative paucity of L2 Chinese pragmatics studies was highlighted once again in Taguchi and Li's (2017) thematic review. Overall, prior research on L2 Chinese pragmatics has investigated pragmatic development in a study abroad and a non-study abroad context, heritage learner pragmatics, and the effectiveness of pragmatics instruction. There are still many gaps to be filled, e.g. pre-departure pragmatics instruction and learning strategy instruction, both of which are addressed in this volume (i.e. Wang \& Halenko; Taguchi, Tang, \& Maa).

Before introducing the papers in this collection, it is worth taking stock of the research specifically in East Asian pragmatics. In sharp contrast to the numerous pragmatic studies of East Asian learners of L2 English and a growing number of cross-cultural pragmatic studies which compare L1 East Asian languages with L1 English, L2 pragmatics of East Asian languages, despite their increasing popu-

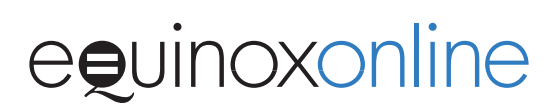


larity around the world, is particularly under-explored. This special issue of East Asian Pragmatics makes an original contribution to bridging the current divide between East Asian pragmatics and second language acquisition research.

With so many potential cross-linguistic and cross-cultural barriers to overcome, in addition to a range of influential variables including individual learner differences which may affect development, the journey to achieving satisfactory levels of pragmatic competence is not a straightforward one. Current investigations into second language pragmatic development have therefore crossed a broad spectrum of investigative contexts and users to better understand the hows and whys of this complex area of second language acquisition. This special issue presents six original papers, organised around two well-researched contexts, namely the 'at-home' environment, examining L1 users or L2 learners in a non-immersive instructional setting (Su \& Chang; Taguchi, Tang, \& Maa; Zheng $\& \mathrm{Xu}$ ), and the 'study abroad' environment, where learners take up temporary residence as part of an L2 sojourn overseas (Inagaki; Kizu, Pizziconi, \& Gyogi; Wang \& Halenko). As discussed earlier, the paucity of research focusing on East Asian language users or learner groups is heavily underexplored, so this collection is a timely and much-needed series of empirical investigations. That this special issue brings together the expertise of new and established researchers in the field of second language pragmatics, who offer insights into a range of common practices or challenges facing the East Asian language user or learner, also makes this collection a worthwhile contribution to a neglected area of the field.

In the opening paper, Taguchi, Tang, and Maa apply strategy instruction to two targeted pragmatic features: conversation opening/closing in L2 Chinese and comprehension of indirect meaning in L2 Japanese. Whilst learning strategies and strategy instruction have generated a host of L2 studies, strategy instruction for L2 pragmatics has received relatively little attention to date. At the onehour strategy instruction session, the researchers taught metacognitive strategies (focus and planning, obtaining resources, and implementing plans) and cognitive strategies (activating knowledge, reasoning, and conceptualizing) to four learners of Chinese and six learners of Japanese respectively in a US university. The metacognitive strategy of monitoring and evaluating was addressed after the session by asking the learners to keep a daily journal for the following two weeks, which was followed by a one-to-one interview. The qualitative investigation has yielded mixed results. On the one hand, Chinese learners reported frequent noticing, detection, and analysis of the target pragmatic feature of conversation opening/closing, though opening was far more frequently reported than closing. On the other hand, Japanese learners rarely reported noticing the target pragmatic feature of indirect meaning. Possible reasons such as the different level of difficulty of the target features and limited opportunities for interaction in

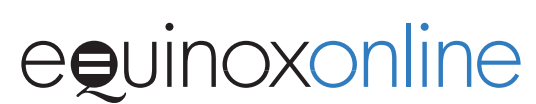


the at-home context were discussed. The findings suggest that strategy instruction may not benefit pragmatic targets and strategy types equally. The preliminary study is a first step to materialise pragmatics learning strategies in strategy instruction and to explore whether strategy instruction can help self-directed learning outside the classroom.

Zheng and Xu's study examines Chinese L2 English learners' perceptions of pragmatic appropriacy of email requests in an at-home context. Whilst email requests of East Asian learners of English have been explored in various aspects, Chinese learners' perceptions of pragmatic appropriacy remain under-researched. The authors developed four questionnaires, each containing five request forms selected and adapted from authentic student emails. The questionnaires were completed by 224 Chinese learners who rated the requests on a five-point Likert scale and answered an open-ended question to reflect on their ratings. Before distributing the questionnaire to the students, the authors asked a small group of 11 native English-speaking instructors to complete the matched guise tests, serving as native-speaker benchmarks for discussions of the student perception results. The findings of the quantitative study revealed that the Chinese L2 learners were highly aware of pragmalinguistic factors, i.e. they perceived requests mitigated by internal and external modifications as more appropriate and polite, but they showed limited or nearly no awareness of sociopragmatic factors, i.e. power difference and high imposition in English requests. The study ends with a call for more explicit L2 sociopragmatic instruction, which is partially answered by Wang and Halenko's study later in the volume.

$\mathrm{Su}$ and Chang look at intra-linguistic pragmatic variation in Mandarin Chinese apologies, with a focus on the effects of region and gender on the use of apology strategies. Prior variational pragmatics research has paid relatively little attention to East Asian languages. This study examined how male and female university students in mainland China and Taiwan performed apologies in Mandarin Chinese. It elicited production data from 40 students from mainland China and 34 students from Taiwan by using a computerised oral discourse completion test (DCT) which had six experimental scenarios with varying degrees of power, distance, and severity of offence. The responses were coded for apology strategies, i.e. illocutionary force indicating device (IFID), intensification, taking on responsibility, explanation/account, and compensation. The results indicate that there was no significant difference between genders, and while there were more similarities than differences across the two regions, the mainland participants used significantly more strategies than the Taiwanese group. The interactional effects between gender and region on the one hand and power relations and severity of offence on the other were found unclear in the study.

Shifting the focus to an immersive language-learning environment, study abroad (SA) may be seen as an ideal place to further one's pragmatic development

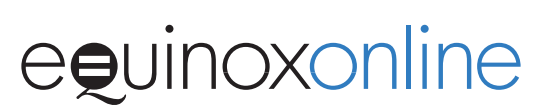


given the frequent exposure to contextualised, local communicative norms, and opportunities for language practice and gaining feedback. However, empirical studies have yielded inconclusive results, with most reporting L2 learners' failure to achieve target-like norms, for some of the reasons described earlier. The studies in this issue are no exception. The three studies featured (Wang \& Halenko; Inagaki; Kizu, Pizziconi, \& Gyogi) are linked in their approach of tracking L2 learners' longitudinal pragmatic development via SA sojourns in China, Japan, and Australia respectively.

Wang and Halenko's study is innovative in its inclusion of L2 Chinese pragmatics instruction at the pre-departure phase of a study abroad sojourn. This investigation draws on qualitative data to examine British and European L2 Chinese learners' perceptions of the beneficial effects of input on the pragmalinguistic (language) and sociopragmatic (culture) features of formulaic sequences before, during, and after a study abroad stay. This combination of features and methodological approach has yet to be found elsewhere in existing second language pragmatics literature. Multi-method participant feedback from three different timephases suggests evidence of pragmalinguistic and sociopragmatic gains from the input of L2 Chinese formulaic expressions, with the latter being received particularly well. For instance, contextualising the formulaic input within the broader Chinese historical and cultural arenas appeared to lead to the L2 Chinese formulaic expressions having more meaningful value. The participants further reported on the practical and psychological benefits of immediate and effective application of the everyday target expressions, which also helped build confidence to interact more whilst overseas.

Kizu, Pizziconi, and Gyogi's study observes the use of the Japanese particle ne in spoken interaction as a marker for development of interactional competence before, during, and after a study abroad stay. The authors further include findings from a six-month delayed test with British learners of L2 Japanese, to measure the sustainability of use of this particle beyond the study abroad period. This methodological design corresponds to calls for studies tracking longer-term learner performance and is insightful for examining study abroad effects in the absence of targeted instruction. In contrast to the positive effects of the study abroad environment found in Wang and Halenko's study, however, the authors are unable to establish a link between study abroad and more frequent production of the particle ne. The authors' findings are able to confirm in part that proficiency plays an important role in the acquisition and development of certain linguistic features, as noted elsewhere and across a range of languages.

In the final paper, Inagaki moves beyond examining linguistic performance in SA to a focus on affective factors, namely motivation. Examples of individual learner differences such as these have been reported to play a critical role in pragmatic development. Drawing on motivational theories such as willingness

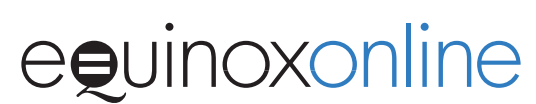


to communicate (WTC), Inagaki's study documents to what extent motivational factors can explain the much-reported variational differences which can occur in pragmatic development during SA. The pre and post SA differences elicited via a Pragmatics Comprehension Test and motivation questionnaire show some signs of development in the comprehension of implicature (conventional not unconventional), which appear to be linked to perceived higher levels of confidence also reported by the Japanese SA participants.

Collectively, these six studies document linguistic and non-linguistic aspects of L1 pragmatic practices and L2 pragmatic development, specifically focusing on East Asian languages. It is hoped one of the outcomes of this special issue will be to incentivise further L1 and L2 research into pragmatic development within and between East Asian languages, given their unique linguistic and cultural characteristics, which continue to be of great appeal to a diverse range of research communities.

\section{References}

Bachman, L. F., \& Palmer, A. S. (1996). Language testing in practice: Designing and developing useful language tests. New York: Oxford University Press.

Canale, M., \& Swain, M. (1980). Theoretical bases of communicative approaches to second language teaching and testing. Applied Linguistics, 1(1), 1-47.

Cohen, A. D. (2008). Teaching and assessing L2 pragmatics: What can we expect from learners? Language Teaching, 41(2), 213-235. https://doi.org/10.1017/ S0261444807004880

Cook, H. M. (2001). Why can't learners of JFL distinguish polite from impolite speech styles? In K. Rose and G. Kasper (Eds.), Pragmatics in language teaching (pp. 80-102). Cambridge: Cambridge University Press. https://doi.org/10.1017/ CBO9781139524797.009

Fantini, A., \& Tirmizi, A. (2006). Exploring and assessing intercultural competence, World Learning Publications, Paper 1. Available online: https:// digitalcollections.sit.edu/cgi/viewcontent.cgi?referer=https://www.google. co.uk/\&httpsredir $=1 \&$ article $=1001 \&$ context=worldlearning_publications $/$ (accessed 27 October 2018).

Hymes, D. (1972). Models of interaction of language and social life. In J. J. Gumperz \& D. H. Hymes (Eds.), Directions in sociolinguistics: The ethnography of communication (pp. 35-71). New York: Holt, Rinehart and Winston.

Ishida, M. (2009). Development of interactional competence: Changes in the use of ne in L2 Japanese during study abroad. In H. Thi Nguyen \& G. Kasper (Eds.), Talk-ininteraction: Multilingual perspectives (pp. 351-385). Honolulu: University of Hawai'i, National Foreign Language Resource Center.

Kasper, G. (Ed.). (1995). Pragmatics of Chinese as native and target language. Honolulu: University of Hawai'i, National Foreign Language Resource Center.

Kasper, G. (1997). Can pragmatic competence be taught? Retrieved 29 March 2009, from Honolulu, University of Hawai'i at Manoa, Second Language Teaching and Curriculum Center., http://www.nflrc.hawaii.edu/ NetWorks/NW06/

\section{equinoxonline}


Kasper, G., \& Rose, K. R. (2002). Pragmatic development in a second language. Malden, MA: Blackwell Publishers.

Kasper, G., \& Zhang, Y. (1995). It's good to be a bit Chinese: Foreign students' experience of Chinese pragmatics. In G. Kasper (Ed.), Pragmatics of Chinese as native and target language (pp. 1-22). Honolulu: University of Hawai'i, National Foreign Language Resource Center.

Leech, G. N. (1983). Principles of pragmatics. London: Longman.

LoCastro, V. (2003). An introduction to pragmatics: Social action for language teachers. Ann Arbor: The University of Michigan Press.

Matsumoto, Y. (1988). Reexamination of the universality of face: Politeness phenomena in Japanese. Journal of Pragmatics, 12(4), 403-426. https://doi.org/10.1016/03782166(88)90003-3

McConachy, T. (2018). Developing intercultural perspectives on language use. Bristol: Multilingual Matters.

Olshtain, E., Blum-Kulka, S. (1985). Degree of approximation: Nonnative reactions to native speech act behavior. In S. Gass, \& C. Madden (Eds.), Input in second language acquisition (pp. 303-325). Rowley: Newbury House.

Pan, Y., \& Kádár, D. Z. (2011). Politeness in historical and contemporary Chinese. London: Continuum.

Sánchez-Hernández, A., \& Alcón-Soler, E. (2018). Pragmatic gains in the study abroad context: Learners' experiences and recognition of pragmatic routines. Journal of Pragmatics, available online. https://doi.org/10.1016/j.pragma.2018.08.006

Taguchi, N. (Ed.). (2009). Pragmatic competence. Berlin: Walter de Gruyter. https://doi. org/10.1515/9783110218558

Taguchi, N. (2010). Longitudinal studies in interlanguage pragmatics. In A. Trosborg (Ed.), Handbook of pragmatics: Vol. 7. Pragmatics across languages and cultures (pp. 333-361). Berlin: Mouton de Gruyter.

Taguchi, N. (2014). Development of interactional competence in Japanese as a second language: Use of incomplete sentences as interactional resources. Modern Language Journal, 98(2), 518-535. https://doi.org/10.1111/modl.12087

Taguchi, N. (2015a). Developing interactional competence in a Japanese study abroad context. Bristol: Multilingual Matters. https://doi.org/10.21832/9781783093731

Taguchi, N. (2015b). Pragmatics in Chinese as a second/foreign language. Studies in Chinese Learning and Teaching, 1(1), 3-17.

Taguchi, N., \& Li, S. (2017). Introduction to a thematic review: Pragmatics research in Chinese as a second language. Chinese as a Second Language Research, 6(1), 1-6.

Thomas, J. (1983). Cross-cultural pragmatic failure. Applied Linguistics, 4(2), 91-112. https://doi.org/10.1093/applin/4.2.91

Young, R. (2011). Interactional competence in language learning, teaching and testing. In E. Hinkel (Ed.), Handbook of research in second language teaching and learning (pp. 426-443). London: Routledge. 